\title{
Association between polymorphisms of OGG1, EPHA2 and age-related cataract risk: a meta-analysis
}

\author{
Hongxu Zhang ${ }^{1}$, Jianguang Zhong ${ }^{1}$, Zhenyu Bian², Xiang Fang ${ }^{3}$, You Peng ${ }^{4}$ and Yongping $\mathrm{Hu}^{1 *}$
}

\begin{abstract}
Background: Evidences have identified the correlation of 8-oxoguanine DNA glycosylase-1 (OGG1) and ephreceptor tyrosine kinase-type A2 (EPHA2) polymorphisms in age-related cataract (ARC) risk. However, the results were not consistent. The objective of this study was to examine the role of these two gene polymorphisms in ARC susceptibility.
\end{abstract}

Methods: Eligible case-control studies published between January 2000 and 2015 were searched and retrieved in the electronic databases. The odds ratio with $95 \%$ confidence interval $(\mathrm{Cl})$ was employed to calculate the strength of the relationship.

Results: We totally screened out six articles, including 5971 cataract patients and 4189 matched controls. Three variants were contained (OGG1 rs1052133; EPHA2 rs7543472 and rs11260867). For OGG1 rs1052133, we detected a significant correlation between OGG1 polymorphism and ARC risk under the heterogenous model (CG vs. CC: $\mathrm{OR}=1.34,95 \% \mathrm{Cl}=1.06-1.70, P=0.01$ ) and dominant model (GG+CG vs. $C \mathrm{C}: \mathrm{OR}=1.45,95 \% \mathrm{Cl}=1.16-1.81, P=0$. 001), especially in patients with cortical cataract of subgroup analysis by phenotypes $(P<0.05)$. For EPHA2 rs7543472 and rs11260867, we did not find a positive association between these two mutations and ARC susceptibility in total cases. Subgroup analysis by phenotypes of cataract showed that only in cortical cataract, genotypes of rs 7543472 under the allele model, homogenous model and recessive model; genotypes of rs11260867 under the heterogenous model and dominant model were associated with ARC risk.

Conclusions: OGG1 rs1052133 (CG and CG+GG genotypes) might be risk factor for ARC, particularly in cortical cataract risk. EPHA2 rs7543472 ( $T$ allele and TT genotype) and rs11260867 (CG and GG+CG genotypes) might be associated with cortical cataract.

Keywords: Age-related cataract, OGG1, EPHA2, Polymorphism, Meta-analysis

\section{Background}

Cataract is a leading cause of blindness and visual impairment throughout the world, increasing the public health and economic burden of this disease [1]. According to the Global estimates of visual impairment, approximate $51 \%$ of blindness and $33 \%$ of visual impairment were estimated due to cataract between 2000 and 2010 [2]. In addition, there are racial/ethnic disparities in the prevalence of cataract [3]:

\footnotetext{
* Correspondence: huypkf@163.com

'Department of Ophtalmology, Hangzhou First People's Hospital, Hangzhou Hospital Affiliated to Nanjing Medical University, Huansha Road No. 261, Hangzhou 310006, Zhejiang, People's Republic of China

Full list of author information is available at the end of the article
}

Cataract of Europeans accounts for $50 \%$ (WHO criteria) to $65 \%$ (US criteria) of unilateral visual impairment, and $45 \%$ (US criteria) of 5-year incident bilateral visual impairment [4]; Asian populations had a higher prevalence and earlier age of onset of cataract than Europeans [5]; while the prevalence of cataract was lower in Africans compared with Europeans [6]. The major risk factors for cataract are age, as well as several demographic and lifestyle characteristics [7, 8]. Approximately $80 \%$ of cataract is agerelated cataract (ARC) [9]. Based on the location of the opacity in the lens, ARC is classified as cortical cataract, nuclear cataract, or posterior subcapsular 
cataract [10]. The prevalence of ARC is rising, with a prediction that 30.1 million Americans will be affected by 2020 [11]. However, its etiology is multifactorial and not fully understood to date.

Etiological research have found that the set of genes were associated with cataract, especially for ARC [12]. In recent years, 8-oxoguanine DNA glycosylase-1 (OGG1) and eph-receptor tyrosine kinase-type A2 (EPHA2) have been identified as key regulators in lens clarity. OGG1 is located in human chromosome $3 \mathrm{p} 26.2$, and its protein is a key enzyme in base excision repair (BER) pathway [13]. It is involved in maintaining genome integrity and preventing cancer development [14]. OGG1 could be used as a therapeutic target for certain types of cancer in monotherapy or combination therapy [15]. OGG1 is also implicated in oxidative mechanisms which play an important role in the pathogenesis of ARC, and might increase the risk of developing ARC [16]. Single nucleotide polymorphism (SNP) of OGG1 was shown to be a risk factor for oxidative pathologies. The most studied variant was OGG1 gene rs1052133 (Ser326Cys), a C to G transversion at nucleotide 1245 , leading to a serine to cysteine substitution at residue 326 located in the Cterminal domain of the protein. The Cys326 protein has been shown to have about 7 times weaker 8hydroxyguanine-repair capacity than Ser326 protein [17]. Homozygous carriers of the S326C OGG1 polymorphism presented reduced repair activity, and C326 OGG1 homozygous carriers might be at increased risk of oxidative pathologies [18].

EPHA2, located in human chromosome 1p36, is a member of the Eph receptor tyrosine kinases family [19]. It is an important regulator of tumor initiation, neo-vascularization and metastasis in a wide range of epithelial and mesenchymal cancers [20, 21]. EPHA2 is highly expressed in aggressive human cancers, and also offers opportunities for $\mathrm{Eph} / \mathrm{ephrin}$-based targeted drug delivery and imaging [22, 23]. EPHA2 protein is expressed in human and mouse lens [24, 25]. Multiple mutations in the EPHA2 gene have been recently shown to cause cataracts in humans, contributing to the destabilization of the receptor and the loss of cell migration activity [26]. The TT genotype of rs7543472 was shown to be associated with $\sim 2 \times$ increased risk for cataracts; rs3754334 might be a variant on the EPHA2 gene that is commonly associated with the risk for ARC in different ethnical and geographical populations [27].

Although epidemiologic studies have identified the correlation of these genes polymorphisms in ARC risk, however, the results remain inconclusive. Therefore, we conducted this meta-analysis to establish the true association between OGG1 and EPHA2 SNPs and the risk for ARC.

\section{Methods}

\section{Identification of eligible articles}

We performed a comprehensive literature search in the following electronic databases of Medline, PubMed, Springer and Elsevier to retrieve relevant articles published between January 2000 and 2015. The key terms were "cataract" or "age-related cataract", "8-oxoguanine glycosylase-1 or OGG1 or DNA repair gene", "Eph-receptor tyrosinekinase-type A2 or EPHA2", and "variant or polymorphism" as well as their combinations. References of related studies were manually searched to obtain more sources. Only studies written in English were included in this meta-analysis.

\section{Criteria for inclusion and exclusion}

The inclusion criteria were as follows: 1) case-control studies concerning the role of OGG1 or EPHA2 polymorphisms in ARC risk; 2) patients with ARC was defined as lens opacity along with disturbance of vision and were over 50 years old (cataract status was determined by lens examination using a slit-lamp biomicroscope; lens opacities were determined using the Lens Opacities Classification System III [28]); controls were age-, sex-, and ethnically matched individuals without history of cataract, hypertension, or other ocular diseases; 3$)$ the genotype information were available to extract, and the results were expressed as odds ratio (OR) with $95 \%$ confidence interval (CI); 4) when the same authors or laboratories reported the issue among the same populations in more articles, only the recent full-text articles were included; and 5) genotype distribution of control for a certain polymorphism must be in HardyWeinberg equilibrium (HWE).

The exclusion criteria were: 1) review reports or conference papers; 2) without control group; 3 ) studies with duplicate data; and 4) genotype information couldn't be extracted.

\section{Quality assessment and data extraction}

Two investigators independently assessed the quality of related articles. Any disagreement was subsequently resolved by discussion with another expert to reach a consensus on all of the items. The following information was extracted from each article: first author, year of publication, country, ethnicity, mean age, sample size, genotyping method, and genotype distribution in cases and controls.

\section{Statistical analysis}

The strength of association between polymorphisms of OGG1, EPHA2 and ARC risk was measured by the pooled ORs with its $95 \% \mathrm{CI}$. The Z test was employed to determine the significance of the pooled ORs, and a $P$ value less than 0.05 was considered statistically significant. For all 
the genetic polymorphisms, the comparison models (allelic model; homogenous model; heterogenous model; dominant model; and recessive model) were examined. The $\mathrm{I}^{2}$ test and the Q-statistic test were used to estimate between-study heterogeneity. The random-effect model was employed when the $P$-value less than 0.10 for the Q-test and $I^{2}$ more than $50 \%$; otherwise, the fixed-effects model was used. The evidence of publication bias was assessed by visual funnel plot inspection. Statistical analyses were conducted in Review Manager (RevMan version 5.3, the Cochrane Collaboration, Oxford, England). All the tests were two-sided.

\section{Results}

\section{Literature search and meta-analysis databases}

We finally screened out 6 relevant articles, including 5971 cataract patients and 4189 controls. Figure 1 presented the flow diagram of searching process. The six studies were conducted in five countries (USA [29], India [30], China [31, 32], Sweden [33], Egypt [34]) and contained three SNPs (one for OGG1: rs1052133; two for EPHA2: rs7543472 and rs11260867). All these articles were written in English, and genetic polymorphisms of OGG1 and EPHA2 were measured by polymerase chain reaction. The genotype distribution in controls were all in accord with HWE $(P>0.05)$. Tables 1 and 2 listed the essential information of included studies in this meta-analysis. Figure 2 presented the distribution of genotype information.

Association between OGG1 rs1052133 (C/G) and ARC risk Table 3 showed the results of test for relationship between OGG1 and EPHA2 polymorphisms and ARC risk based on different genetic models in total and subgroup analysis.

Three articles concerned the OGG1 variant, including 1069 patients and 680 controls. Although the frequency of $\mathrm{G}$ allele (minor) was shown to be higher in ARC cases than that in controls (45.4 versus $35.5 \%$ ), our result found that the $G$ allele was not associated with ARC susceptibility in the random-effect model $(\mathrm{OR}=1.36,95 \% \mathrm{CI}=0.99-1.87, P=0.05)$. This insignificance was also found under the homogenous model and recessive model $(P>0.05)$. But we detected a significant correlation between OGG1 polymorphism and ARC risk in the heterogenous model (CG vs. $\mathrm{CC}: \quad \mathrm{OR}=1.34,95 \% \mathrm{CI}=1.06-1.70, \quad P=0.01)$ and dominant model (GG+CG vs. $\mathrm{CC}$ : $\mathrm{OR}=1.45,95 \% \mathrm{CI}$ $=1.16-1.81, P=0.001)$ in the fixed-effect model as shown in Fig. 2. Subgroup analysis by phenotypes of cataract showed that only in cortical, not nuclear or posterior subcapsular cataract, OGG1 variant was associated with increased the risk of ARC under the heterogenous model ( $\mathrm{CG}$ vs. $\mathrm{CC}$ : $\mathrm{OR}=1.43,95 \% \mathrm{CI}$ $=1.04-1.96, P=0.03)$ and dominant model $(\mathrm{GG}+\mathrm{CG}$ vs. $\quad \mathrm{CC}$ : $\mathrm{OR}=1.54,95 \% \mathrm{CI}=1.15-2.07, \quad P=0.004)$. Figure 3 showed the relative strength of the association between OGG1 rs1052133 and different types of cataract under the heterogenous model.

\section{Association between EPHA2 rs7543472 (C/T), rs 11260867 (C/G) and ARC risk}

Three articles contained 4902 cases and 3509 controls evaluating the association of EPHA2 genetic polymorphisms and ARC occurrence. For rs7543472, our result found that this variant was not associated with ARC risk
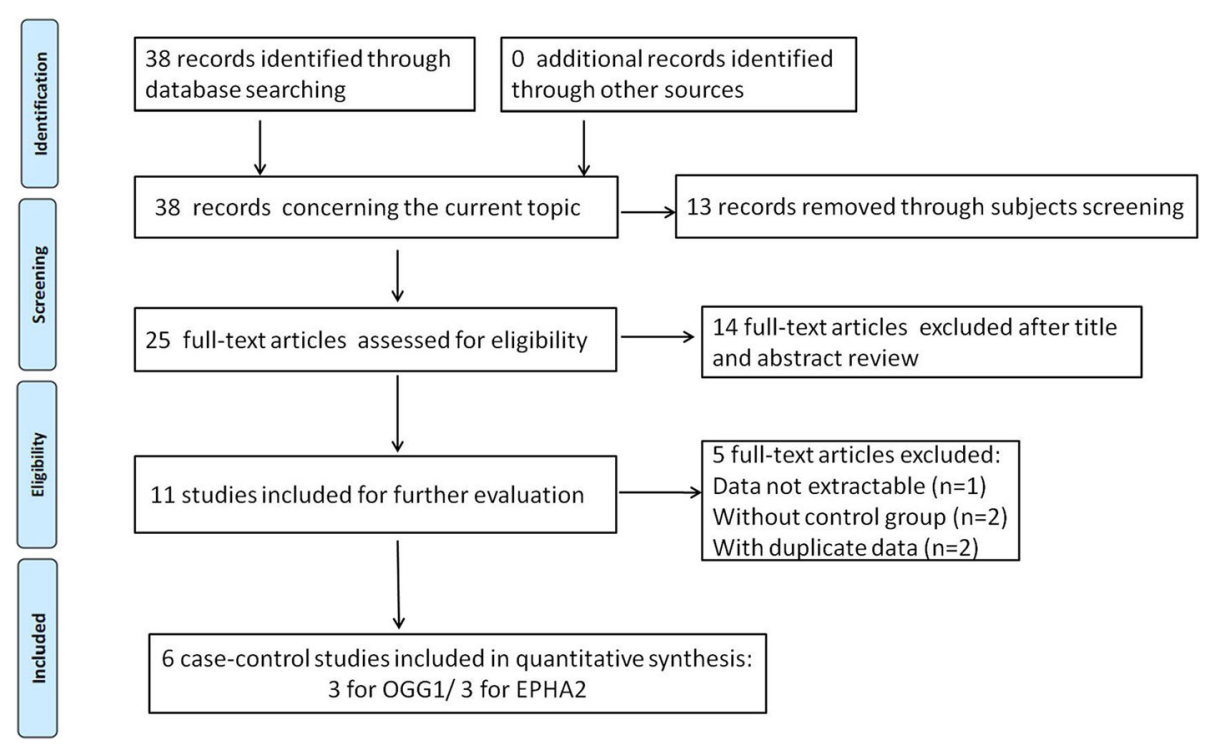

Fig. 1 Flow chart of selection process 
Table 1 Main characteristics of included studies in this meta-analysis

\begin{tabular}{|c|c|c|c|c|c|c|c|c|}
\hline \multirow[t]{2}{*}{ First author } & \multirow[t]{2}{*}{ Year } & \multirow[t]{2}{*}{ Country } & \multirow[t]{2}{*}{ Ethnicity } & \multicolumn{2}{|l|}{ Mean age } & \multicolumn{2}{|c|}{ Sample size } & \multirow{2}{*}{$\begin{array}{l}\text { Genotype } \\
\text { methods }\end{array}$} \\
\hline & & & & ARCs & Controls & ARCS & Controls & \\
\hline Shiels A [29] & 2008 & USA & European & $75.7 \pm 7.9$ & $74.5 \pm 7.6$ & 213 & 104 & PCR \\
\hline Sundaresan P [30] & 2012 & India & Asian & - & - & 4198 & 3220 & PCR \\
\hline Zhang Y [31] & 2012 & China & Asian & $67.17 \pm 6.92$ & $65.77 \pm 6.49$ & 415 & 386 & PCR-RFLP \\
\hline Jiang SQ [32] & 2013 & China & Asian & $70.9 \pm 8.2$ & $60.2 \pm 5.7$ & 504 & 244 & PCR \\
\hline Celojevic D [33] & 2014 & Sweden & European & $72 \pm 8.7$ & $66 \pm 6.9$ & 491 & 185 & PCR \\
\hline Gharib AF [34] & 2014 & Egypt & African & $60.33 \pm 6.22$ & $67.83 \pm 5.54$ & 150 & 50 & PCR \\
\hline
\end{tabular}

$\overline{A R C}$ age-related cataract, - not available, $P C R-R F L P$ polymerase chain reaction-restriction fragment length polymorphism

under any genetic models ( $\mathrm{T}$ vs. $\mathrm{C}: \mathrm{OR}=1.13,95 \% \mathrm{CI}=$ $0.92-1.38, P=0.25$; TT vs. $\mathrm{CC}: \mathrm{OR}=1.23,95 \% \mathrm{CI}=0.99$ $1.52, P=0.06$; TC vs. $\mathrm{CC}: \mathrm{OR}=1.06,95 \% \mathrm{CI}=0.96-1.17$, $P=0.22$; TT + TC vs. $\mathrm{CC}: \mathrm{OR}=1.08,95 \% \mathrm{CI}=0.99-1.19$, $P=0.10$; TT vs. TC+CC: $\mathrm{OR}=1.24,95 \% \mathrm{CI}=0.90-1.72$, $P=0.18$ ). Subgroup analysis by phenotypes of cataract showed a significant relationship between rs7543472 and cortical cataract under the allele model $(\mathrm{OR}=1.16,95 \%$ $\mathrm{CI}=1.01-1.33, P=0.03)$, homogenous model $(\mathrm{OR}=1.52$, $95 \% \mathrm{CI}=1.05-2.18, P=0.03)$ and recessive model $(\mathrm{OR}=$ $1.54,95 \% \mathrm{CI}=1.18-2.01, P=0.001)$ in the fixed-effect model as shown in Fig. 4. No association was detected between rs7543472 and patients with nuclear cataract under any genetic models.

For rs11260867, we did not observe a significant positive correlation between this variant and ARC risk under any genetic models as well (Table 3). Subgroup analysis by phenotypes of cataract showed that this variant was associated with increased the risk of cortical cataract, not nuclear cataract under the heterogenous model (CG vs. $\mathrm{CC}$ : $\mathrm{OR}=0.66,95 \% \mathrm{CI}=$ $0.43-1.00, P=0.05)$ and dominant model $(\mathrm{GG}+\mathrm{CG}$ vs. CC: $\mathrm{OR}=0.66,95 \% \mathrm{CI}=0.44-0.99, P=0.04)$ as shown in Fig. 5.

\section{Sensitivity analysis and publication bias evaluation}

To confirm whether each included study influences the overall results or not, we successively omitted each single study, respectively. Our result found that the pooled ORs were not significantly changed. The funnel plots were used to evaluate the publication bias. All the plots were found to be roughly symmetrical, indicating no publication bias presented as shown in Fig. 6 .

\section{Discussion}

In this meta-analysis, we totally identified six articles concerning three genetic polymorphisms. Our results showed that CG genotype and GG+CG genotype of OGG1 rs1052133 were associated with increased the risk of ARC, in particular with cortical cataract. This significant relationship was not found in EPHA2 polymorphisms (rs7543472 and rs11260867), however, subgroup analysis by phenotypes of cataract showed that only in cortical cataract, the genotypes of rs7543472 under the allele model, homogenous model and recessive model; genotypes of rs11260867 under the heterogenous model and dominant model were associated with ARC risk. This was the first meta-analysis concerning these three SNPs in ARC risk.

Table 2 Genotype distribution of OGG1 and EPHA2 polymorphisms in cataract cases and controls

\begin{tabular}{|c|c|c|c|c|c|c|c|c|c|c|c|}
\hline \multirow{2}{*}{$\frac{\text { First author }}{\text { rs } 1052133}$} & \multicolumn{5}{|l|}{ ARCs } & \multicolumn{5}{|c|}{ Controls } & \multirow[t]{2}{*}{$\mathrm{HWE}$} \\
\hline & CC & $C G$ & GG & C & G & CC & CG & GG & C & G & \\
\hline Zhang Y [31] & 222 & 153 & 40 & 597 & 233 & 247 & 120 & 19 & 614 & 158 & 0.68 \\
\hline Jiang SQ [32] & 72 & 222 & 210 & 366 & 642 & 40 & 103 & 101 & 183 & 305 & 0.29 \\
\hline Gharib AF [34] & 77 & 51 & 22 & 205 & 95 & 32 & 16 & 2 & 80 & 20 & 1.00 \\
\hline rs7543472 & $\pi$ & TC & CC & $\mathrm{T}$ & C & $\pi$ & $\mathrm{TC}$ & CC & $\mathrm{T}$ & C & \\
\hline Shiels A [29] & 146 & 53 & 5 & 345 & 63 & 58 & 41 & 3 & 157 & 47 & 0.40 \\
\hline Sundaresan P [30] & 202 & 1419 & 2569 & 1823 & 6557 & 128 & 1054 & 2028 & 1310 & 5110 & 0.83 \\
\hline Celojevic D [33] & 298 & 163 & 30 & 759 & 223 & 115 & 58 & 12 & 288 & 82 & 0.46 \\
\hline rs11260867 & CC & CG & GG & C & G & CC & CG & GG & C & G & \\
\hline Shiels A [29] & 4 & 43 & 166 & 51 & 375 & 1 & 33 & 68 & 35 & 169 & 0.38 \\
\hline Sundaresan P [30] & 25 & 623 & 3527 & 673 & 7677 & 24 & 448 & 2725 & 496 & 5898 & 0.50 \\
\hline Celojevic D [33] & 317 & 158 & 16 & 792 & 190 & 121 & 58 & 6 & 300 & 70 & 0.96 \\
\hline
\end{tabular}




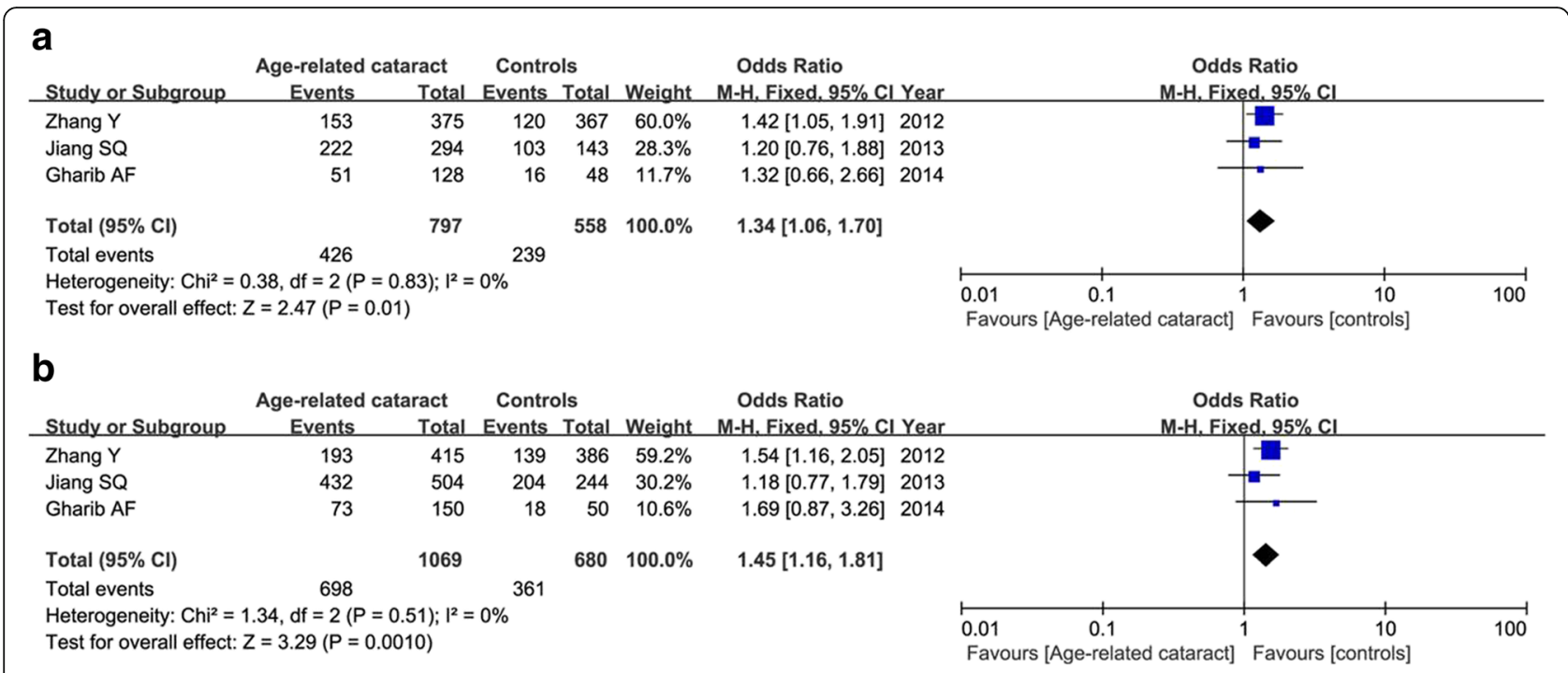

Fig. 2 Meta-analysis of the relationship between the OGG1 rs1052133 and age-related cataract under the heterogenous model (a: CG vs. CC) and dominant model (b: GG+CG vs. CC)

Cataract is the single largest contributor to blindness in the world. Age is the major risk factor for cataract. Even though several measures have been identified as a solution for cataract treatment $[35,36]$, there is no obvious therapeutic benefits, and established medical treatment for better prevention and treatment of cataract was not built [37]. Moreover, this disease has a strong genetic component. Therefore, understanding of genetic polymorphisms within the lens may provide an insight into the process of cataract onset.

OGG1 is involved in multiple vital processes. Recent studies showed that OGG1 was highly expressed in the

Table 3 Meta-analysis of OGG1 and EPHA2 polymorphisms in ARC based on different genetic models

\begin{tabular}{|c|c|c|c|c|c|c|c|c|}
\hline \multirow[t]{2}{*}{ Comparisons } & \multicolumn{2}{|l|}{ Total } & \multicolumn{2}{|l|}{ Cortical cataract } & \multicolumn{2}{|l|}{ Nuclear cataract } & \multicolumn{2}{|l|}{ PSC } \\
\hline & $\mathrm{OR}(95 \% \mathrm{Cl})$ & $P$ & $\mathrm{OR}(95 \% \mathrm{Cl})$ & $P$ & OR (95 \% Cl) & $P$ & OR $(95 \% \mathrm{Cl})$ & $P$ \\
\hline \multicolumn{9}{|l|}{ rs1052133 } \\
\hline G vs. C & $1.36(0.99,1.87)$ & 0.05 & $1.50(0.97,2.32)$ & 0.07 & $1.23(0.98,1.55)$ & 0.07 & $1.26(0.94,1.68)$ & 0.12 \\
\hline GG vs. CC & $1.88(0.96,3.71)$ & 0.07 & $2.18(0.90,5.28)$ & 0.08 & $1.45(0.87,2.44)$ & 0.16 & $1.61(0.83,3.09)$ & 0.16 \\
\hline CG vs. CC & $1.34(1.06,1.70)$ & 0.01 & $1.43(1.04,1.96)$ & 0.03 & $1.32(0.93,1.86)$ & 0.12 & $1.22(0.79,1.88)$ & 0.37 \\
\hline GG+CG vs. CC & $1.45(1.16,1.81)$ & 0.001 & $1.54(1.15,2.07)$ & 0.004 & $1.37(0.99,1.90)$ & 0.06 & $1.32(0.88,1.99)$ & 0.18 \\
\hline GG vs. $C G+C C$ & $1.65(0.82,3.32)$ & 0.16 & $1.83(0.78,4.29)$ & 0.17 & $1.18(0.79,1.75)$ & 0.43 & $1.30(0.78,2.17)$ & 0.31 \\
\hline \multicolumn{9}{|l|}{ rs7543472 } \\
\hline T vs. C & $1.13(0.92,1.38)$ & 0.25 & $1.16(1.01,1.33)$ & 0.03 & $1.04(0.75,1.43)$ & 0.83 & & \\
\hline TT vs. CC & $1.23(0.99,1.52)$ & 0.06 & $1.52(1.05,2.18)$ & 0.03 & $1.08(0.84,1.39)$ & 0.55 & & \\
\hline TC vs. CC & $1.06(0.96,1.17)$ & 0.22 & $0.99(0.82,1.20)$ & 0.94 & $1.03(0.92,1.15)$ & 0.61 & & \\
\hline $\mathrm{TT}+\mathrm{TC}$ vs. CC & $1.08(0.99,1.19)$ & 0.10 & $1.06(0.88,1.27)$ & 0.53 & $1.04(0.93,1.16)$ & 0.49 & & \\
\hline TT vs. TC+CC & $1.24(0.90,1.72)$ & 0.18 & $1.54(1.18,2.01)$ & 0.001 & $1.11(0.72,1.70)$ & 0.63 & & \\
\hline \multicolumn{9}{|l|}{ rs11260867 } \\
\hline G vs. C & $0.99(0.89,1.11)$ & 0.88 & $0.89(0.73,1.07)$ & 0.20 & $1.09(0.84,1.40)$ & 0.52 & & \\
\hline GG vs. CC & $1.14(0.71,1.83)$ & 0.59 & $0.62(0.31,1.24)$ & 0.18 & $1.38(0.76,2.49)$ & 0.29 & & \\
\hline CG vs. CC & $1.08(0.80,1.47)$ & 0.60 & $0.66(0.43,1.00)$ & 0.05 & $1.46(0.95,2.23)$ & 0.08 & & \\
\hline GG+CG vs. CC & $1.08(0.80,1.45)$ & 0.62 & $0.66(0.44,0.99)$ & 0.04 & $1.43(0.94,2.18)$ & 0.09 & & \\
\hline GG vs. CG+CC & $1.16(0.74,1.81)$ & 0.52 & $1.19(0.55,2.59)$ & 0.66 & $0.95(0.83,1.10)$ & 0.50 & & \\
\hline
\end{tabular}




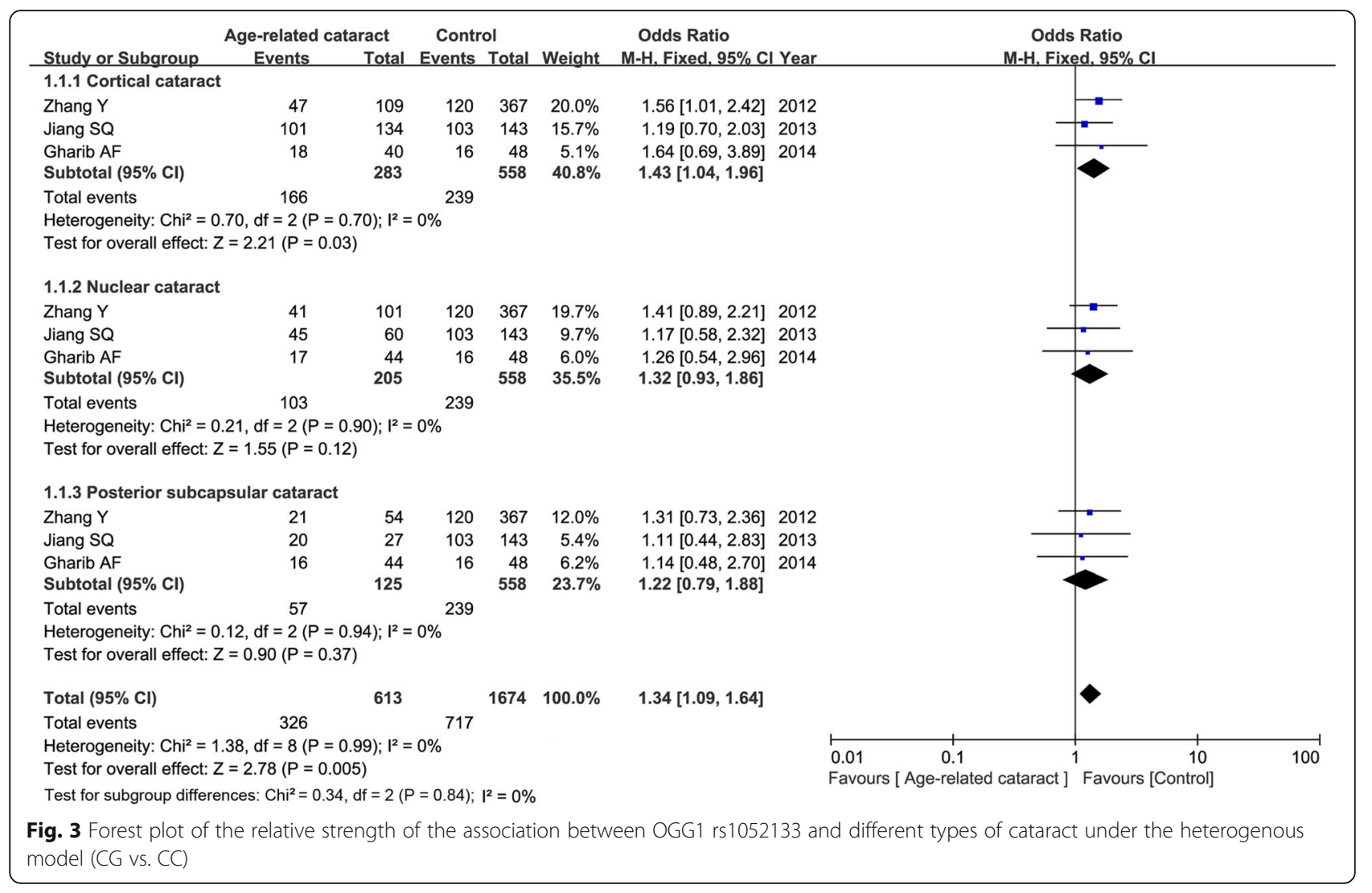

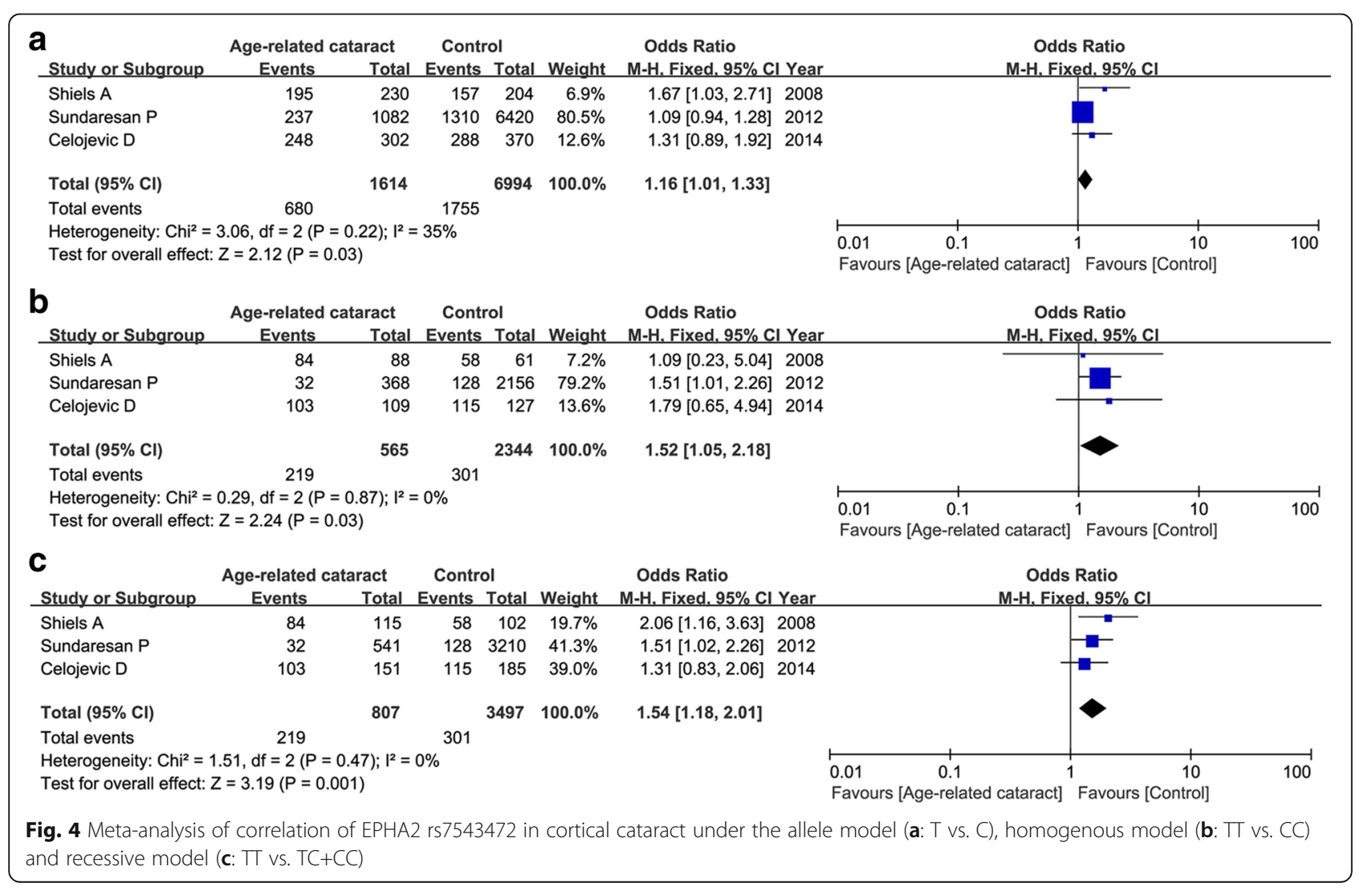




\begin{tabular}{|c|c|c|c|c|c|c|c|c|c|}
\hline \multicolumn{10}{|l|}{ a } \\
\hline & \multicolumn{2}{|c|}{ Age-related cataract } & \multicolumn{2}{|c|}{ Control } & \multicolumn{2}{|r|}{ Odds Ratio } & \multirow{2}{*}{\multicolumn{3}{|c|}{$\begin{array}{c}\text { Odds Ratio } \\
\text { M-H. Fixed, } 95 \% \mathrm{Cl}\end{array}$}} \\
\hline Study or Subgroup & Events & \multirow{2}{*}{$\frac{\text { Total }}{21}$} & Events $T$ & Total & Weight & M-H. Fixed. $95 \%$ Cl Year & & & \\
\hline Shiels A & 19 & & 33 & 34 & $4.5 \%$ & $0.29[0.02,3.39] 2008$ & \\
\hline Sundaresan $P$ & 86 & 93 & 448 & 472 & $20.9 \%$ & $0.66[0.27,1.58] 2012$ & & & \\
\hline Celojevic D & 36 & 147 & 58 & 179 & $74.5 \%$ & $0.68[0.41,1.10] 2014$ & & & \\
\hline Total $(95 \% \mathrm{Cl})$ & & 261 & & 685 & $100.0 \%$ & $0.66[0.43,1.00]$ & & & \\
\hline Total events & 141 & & 539 & & & & & & \\
\hline \multicolumn{7}{|c|}{$\begin{array}{l}\text { Heterogeneity: } C \mathrm{Ch}^{2}=0.44, \mathrm{df}=2(P=0.80) ; \mathrm{l}^{2}=0 \% \\
\text { Test for overall effect: } Z=1.97(P=0.05)\end{array}$} & $\begin{array}{lll}0.01 & 0.1 & 1 \\
\text { Favours [Age-related cataract] }\end{array}$ & 1 Favours [Control] & 100 \\
\hline \multicolumn{10}{|c|}{ 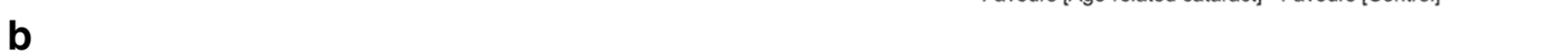 } \\
\hline Study or Subgroup & Events & Total & Events & Total & Weight & M-H. Fixed. $95 \% \mathrm{Cl}$ Year & \multicolumn{3}{|c|}{$\begin{array}{c}\text { Odds Ratio } \\
\text { M-H. Fixed, } 95 \% \mathrm{Cl}\end{array}$} \\
\hline Shiels A & 117 & 119 & 101 & 102 & $3.3 \%$ & $0.58[0.05,6.48] 2008$ & & & \\
\hline Sundaresan $P$ & 531 & 538 & 3173 & 3197 & $21.2 \%$ & $0.57[0.25,1.34] 2012$ & & & \\
\hline Celojevic D & 40 & 151 & 64 & 185 & $75.5 \%$ & $0.68[0.43,1.09] 2014$ & & & \\
\hline Total $(95 \% \mathrm{Cl})$ & & 808 & & 3484 & $100.0 \%$ & $0.66[0.44,0.99]$ & & & \\
\hline Total events & 688 & & 3338 & & & & & & \\
\hline $\begin{array}{l}\text { Heterogeneity: } \mathrm{Chi}^{2}= \\
\text { Test for overall effect: }\end{array}$ & $\begin{array}{l}0.13, d f=2(P= \\
Z=2.03(P=0.0\end{array}$ & $94) ; 1^{2}=c$ & & & & & $\begin{array}{lcl}0.01 & 0.1 & 1 \\
\text { Favours [Age-related cataract] }\end{array}$ & 1 Favours [Control] & 100 \\
\hline
\end{tabular}

embryonic brain, and lack of OGG1 might cause severe brain defects in brain integrity, balance and mobility [38]. The acetylation of OGG1 was shown to play an important etiologic role in regulating its function in response to DNA damage [39], and could be one of the mechanisms for ARC development [40]. Xu et al. proved that OGG1 might increase in lens epithelium cells with $\mathrm{ARC}$, and the alteration of OGG1 level was associated with the location and opaque degrees of lens [41]. Wang et al. proved that the reduced OGG1 expression was correlated with hypermethylation of a CpG island of OGG1 in lens cortex of ARC [42]. In addition, OGG1 mutations might delay the repair of oxidative DNA damage, and be associated with increased disease risk [43]. Ali et al. showed that OGG1 mutation may prove to be a good candidate of better diagnosis, treatment, and prevention of breast cancer [44]. Zhang et al. suggested that OGG1 Ser326Cys polymorphism might be associated with increased risk of ARC [31]. While Su et al. did not find a correlation between OGG1 variants and ARC risk in Han Chinese from the Jiangsu Eye Study [45].

EPHA2 is an epithelial cell tyrosine kinase, and was shown to be enriched in adult tissues [46]. It is highly expressed in aggressive human cancers. During tumor progression, EPHA2 receptor can gain ligandindependent pro-oncogenic functions due to Akt activation and reduced ephrin-A ligand engagement [47]. Moreover, EPHA2 can function as a therapeutic target for antibody therapy of cancers and diseases [48, 49]. Dunne et al. found that EPHA2 was a key driver of invasion and migration and a synthetically lethal target in KRASMT colorectal cancer, indicating that EPHA2 was a poor prognostic marker [50]. Kato et al. showed a promising role for EPHA2 as a target for antibody treatment in melanoma and enhanced the therapeutic effect as an agonistic antibody to EPHA2 [51]. Genetic and pharmacological inhibition of EPHA2 induces apoptosis and abrogates tumorigenic growth of tumor cells [52]. Recent studies have identified EPHA2 as a surprisingly abundant plasma membrane component in cells of the ocular lens [53]. Mutations in EPHA2 have been shown to underlie inherited forms of cataract in humans [54, 55]. Common variants in EPHA2 have been associated with the much more prevalent age-related form of cataract. Dave et al. showed that mutations in EPHA2 accounted for $4.7 \%$ of inherited cataract cases in SouthEastern Australia, and a rare variant rs139787163 was potentially associated with increased susceptibility to cataract, providing a link between congenital and agerelated cataract [56]. Furthermore, the cytoprotective and antiapoptotic function of EPHA2 in lens epithelial cells was abolished by the functional polymorphisms [52]. These results indicated the potential role of EPHA2 in maintaining lens clarity during aging by promoting cell viability.

Several limitations were presented in this metaanalysis. First of all, the number of included studies for each SNP was small, future large-scale researches with more ethnicities are needed to further evaluate the relationship. Secondly, between-study heterogeneity was presented in several comparisons. Thirdly, we did not conduct the subgroup analysis by ethnicities due to the less data, which should be concerned in the future. Lastly, gene-gene and geneenvironment interactions were not addressed in our meta-analysis. 

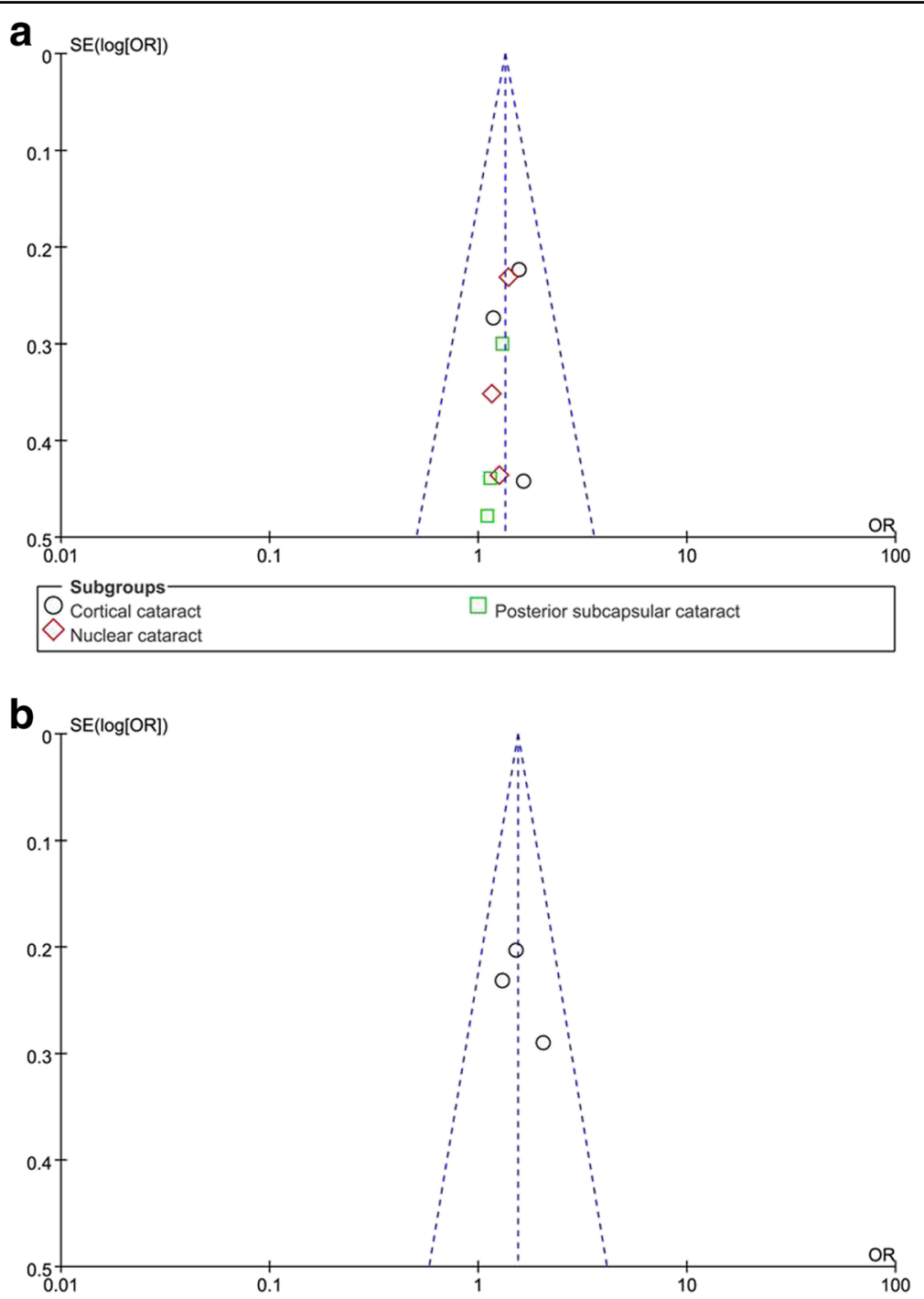

Fig. 6 Funnel plot of a: OGG1 rs1052133 under the heterogenous model (CG vs. CC); b: EPHA2 rs7543472 under the recessive model (TT vs. TC+CC) in cataract risk

\section{Conclusions}

Our results indicated that CG genotype and GG+CG genotype of OGG1 rs1052133 might be risk factor for ARC, especially in cortical cataract risk. The $\mathrm{T}$ allele and TT genotype of EPHA2 rs7543472; CG genotype and GG+CG genotype of EPHA2 rs11260867 were associated with cortical cataract risk. Future studies are still required to re-evaluate the results of OGG1 and EPHA2 polymorphisms in ARC risk.

\section{Abbreviations}

ARC: Age-related cataract; BER: Base excision repair; Cl: Confidence interval; EPHA2: Eph-receptor tyrosine kinase-type A2; HWE: Hardy-Weinberg equilibrium; OGG1: 8-oxoguanine DNA glycosylase-1; OR: Odds ratio; SNP: Single nucleotide polymorphism

\section{Funding}

This study was supported by National Natural Science Foundation of China (Grant No.: 81472511).

\section{Availability of data and materials}

All data has been shared in the Figures and Tables.

\section{Authors' contributions}

YH made substantial contributions to conception and design of this study: $\mathrm{HZ}$, JZ and ZB made substantial contributions to acquisition of data, or analysis and interpretation of data; $\mathrm{HZ}, \mathrm{XF}$ and YP drafted the manuscript; YH revised it critically for important intellectual content and agreed to be accountable for all aspects of the work in ensuring that questions related to the accuracy or integrity of any part of the work are appropriately investigated and resolved. All authors have given the final approval of the version to be published.

\section{Competing interests}

No conflict of interest exists. 


\section{Consent for publication}

Not applicable.

\section{Ethics approval and consent to participate}

Not applicable.

\section{Author details}

'Department of Ophtalmology, Hangzhou First People's Hospital, Hangzhou Hospital Affiliated to Nanjing Medical University, Huansha Road No. 261, Hangzhou 310006, Zhejiang, People's Republic of China. ${ }^{2}$ Department of Orthopaedics, Hangzhou First People's Hospital, Hangzhou Hospital Affiliated to Nanjing Medical University, Hangzhou 310006, Zhejiang, People's Republic of China. ${ }^{3}$ Department of Central Laboratory, Hangzhou First People's Hospital, Hangzhou Hospital Affiliated to Nanjing Medical University, Hangzhou 310006, Zhejiang, People's Republic of China. ${ }^{4}$ Department of Surgical Oncology, Hangzhou First People's Hospital, Hangzhou Hospital Affiliated to Nanjing Medical University, Hangzhou 310006, Zhejiang, People's Republic of China.

Received: 8 June 2016 Accepted: 2 September 2016 Published online: 29 September 2016

\section{References}

1. Javitt JC, Wang F, West SK. Blindness due to cataract: epidemiology and prevention. Annu Rev Public Health. 1996;17(1):159-77.

2. Pascolini D, Mariotti SP. Global estimates of visual impairment: 2010. Br J Ophthalmol. 2011:bjophthalmol-2011-300539

3. Storey P, Munoz B, Friedman D, West S. Racial differences in lens opacity incidence and progression: the Salisbury Eye Evaluation (SEE) study. Invest Ophthalmol Vis Sci. 2013;54:3010-8.

4. Gunnlaugsdottir E, Arnarsson A, Jonasson F. Five-year incidence of visual impairment and blindness in older Icelanders: the Reykjavik Eye Study. Acta Ophthalmol. 2010;88(3):358-66.

5. Chua J, Koh JY, Tan AG, Zhao W, Lamoureux E, Mitchell P, Wang JJ, Wong TY, Cheng C-Y. Ancestry, socioeconomic status, and age-related cataract in Asians: the Singapore Epidemiology of Eye Diseases study. Ophthalmology. 2015;122(11):2169-78.

6. Klein R, Klein BE. The prevalence of age-related eye diseases and visual impairment in aging: current estimates. Invest Ophthalmol Vis Sci. 2013; 54(14):ORSF5

7. Virgolici B, Popescu L. [Risk factors in cataract]. Oftalmologia (Bucharest, Romania: 1990). 2005;50(2):3-9.

8. Daien V, Le Pape A, Heve D, Carriere I, Villain M. Incidence, risk factors, and impact of age on retinal detachment after cataract surgery in France: a national population study. Ophthalmology. 2015;122(11):2179-85.

9. West S. Epidemiology of cataract: accomplishments over 25 years and future directions. Ophthalmic Epidemiol. 2007;14(4):173-8.

10. Domalpally A, Danis RP, Chew EY, Clemons TE, Reed S, SanGiovanni JP, Ferris III FL. Evaluation of optimized digital fundus reflex photographs for lens opacities in the age-related eye disease study 2: AREDS2 report 7. Invest Ophthalmol Vis Sci. 2013;54(9):5989.

11. Goldman HB, Kiffel S, Weinstock FJ. Cataract surgery and the primary care practitioner. Geriatrics. 2009;64(5):19-22. 25-16.

12. Shiels A, Hejtmancik J. Genetics of human cataract. Clin Genet. 2013;84(2): 120-7.

13. Smith TB, Dun MD, Smith ND, Curry BJ, Connaughton HS, Aitken RJ. The presence of a truncated base excision repair pathway in human spermatozoa that is mediated by OGG1. J Cell Sci. 2013;126(6):1488-97.

14. Yuzeforych LV, Kahn AG, Schuler MA, Eide L, Arora R, Wilson GL, Tan M, Rachek LI. Mitochondrial DNA repair through OGG1 activity attenuates breast cancer progression and metastasis. Cancer Res. 2015:canres. 0692.2015

15. Donley N, Jaruga P, Coskun E, Dizdaroglu M, McCullough AK, Lloyd RS. Small molecule inhibitors of 8-oxoguanine DNA glycosylase-1 (OGG1). ACS Chem Biol. 2015;10(10):2334-43.

16. Selin JZ, Lindblad BE, Rautiainen S, Michaëlsson K, Morgenstern R, Bottai M, Basu S, Wolk A. Are increased levels of systemic oxidative stress and inflammation associated with age-related cataract? Antioxid Redox Signal. 2014;21(5):700-4.

17. Kohno T, Shinmura K, Tosaka M, Tani M, Kim S-R, Sugimura H, Nohmi T, Kasai H, Yokota J. Genetic polymorphisms and alternative splicing of the
hOGG1 gene, that is involved in the repair of 8-hydroxyguanine in damaged DNA. Oncogene. 1998;16(25):3219-25.

18. Simonelli V, Camerini S, Mazzei F, Van Loon B, Allione A, D'Errico M, Barone F, Minoprio A, Ricceri F, Guarrera S. Genotype-phenotype analysis of S326C OGG1 polymorphism: a risk factor for oxidative pathologies. Free Radic Biol Med. 2013:63:401-9.

19. Son Al, Park JE, Zhou R. The role of Eph receptors in lens function and disease. Science China Life Sciences. 2012;55(5):434-44.

20. Koshikawa N, Hoshino D, Taniguchi H, Minegishi T, Tomari T, Nam S-O, Aoki M, Sueta T, Nakagawa T, Miyamoto S. Proteolysis of EphA2 converts it from a tumor suppressor to an oncoprotein. Cancer Res. 2015;75(16):3327-39.

21. Borthakur S, Lee H, Kim S, Wang B-C, Buck M. Binding and function of phosphotyrosines of the Ephrin A2 (EphA2) receptor using synthetic Sterile a Motif (SAM) domains. J Biol Chem. 2014;289(28):19694-703.

22. Barquilla A, Pasquale EB. Eph receptors and ephrins: therapeutic opportunities. Annu Rev Pharmacol Toxicol. 2015:55:465-87.

23. Tandon M, Vemula SV, Mittal SK. Emerging strategies for EphA2 receptor targeting for cancer therapeutics. Expert Opin Ther Targets. 2011;15(1):31-51.

24. Jun G, Guo H, Klein B, Klein R, Wang JJ, Mitchell P, Miao H, Lee KE, Joshi T, Buck M. EPHA2 is associated with age-related cortical cataract in mice and humans. PLoS Genet. 2009;5(7):e1000584.

25. Tan W, Hou S, Jiang Z, Hu Z, Yang P, Ye J. Association of EPHA2 polymorphisms and age-related cortical cataract in a Han Chinese population. Mol Vis. 2011;17:1553.

26. Park JE, Son Al, Hua R, Wang L, Zhang X, Zhou R. Human cataract mutations in EPHA2 SAM domain alter receptor stability and function. PLoS One. 2012; 7(5):e36564.

27. Yang J, Luo J, Zhou P, Fan Q, Luo Y, Lu Y. Association of the ephreceptor tyrosinekinase-type A2 (EPHA2) gene polymorphism rs3754334 with agerelated cataract risk: a meta-analysis. PLoS One. 2013:8(8):e71003.

28. Chylack LT, Wolfe JK, Singer DM, Leske MC, Bullimore MA, Bailey IL, Friend J, McCarthy D, Wu S-Y. The lens opacities classification system III. Arch Ophthalmol. 1993;111(6):831-6

29. Shiels A, Bennett TM, Knopf HL, Maraini G, Li A, Jiao X, Hejtmancik JF. The EPHA2 gene is associated with cataracts linked to chromosome $1 \mathrm{p}$. Mol Vis. 2008;14:2042.

30. Sundaresan $P$, Ravindran RD, Vashist $P$, Shanker A, Nitsch D, Talwar B, Maraini G, Camparini M, Nonyane BAS, Smeeth L. EPHA2 polymorphisms and age-related cataract in India. 2012.

31. Zhang Y, Zhang L, Song Z, Sun DL, Liu HR, Fu SB, Liu DR, Liu P. Genetic polymorphisms in DNA repair genes OGG1, APE1, XRCC1, and XPD and the risk of age-related cataract. Ophthalmology. 2012;119(5):900-6.

32. Jiang S, Hu N, Zhou J, Zhang J, Gao R, Hu J, Guan H. Polymorphisms of the WRN gene and DNA damage of peripheral lymphocytes in ageelated cataract in a Han Chinese population. Age. 2013;35(6):2435-44.

33. Celojevic D, Abramsson A, Seibt Palmér M, Tasa G, Juronen E, Zetterberg $H$, Zetterberg M. EPHA2 polymorphisms in Estonian patients with age-related cataract. Ophthalmic Genet. 2014(0):1-5

34. Gharib AF, Dabour SA, Etewa RL, Fouad RA. Polymorphisms of DNA repair genes OGG1 and XPD and the risk of age-related cataract in Egyptians. Mol Vis. 2014;20:661.

35. Laroche L. Actuality in cataract treatment. La Revue du praticien. 2013;63(1): $43-7$

36. Lin H, Chen W, Luo L, Congdon N, Zhang X, Zhong X, Liu Z, Chen W, Wu C, Zheng $D$. Effectiveness of a short message reminder in increasing compliance with pediatric cataract treatment: a randomized trial. Ophthalmology. 2012;119(12):2463-70.

37. Boyd S. Preoperative selection for cataract surgery. Recent Trends in Cataract Management. 2013;1:1

38. Gu A, Ji G, Yan L, Zhou Y. The 8-oxoguanine DNA glycosylase 1 (ogg1) decreases the vulnerability of the developing brain to DNA damage. DNA Repair. 2013;12(12):1094-104.

39. Scott TL, Rangaswamy S, Wicker CA, Izumi T. Repair of oxidative DNA damage and cancer: recent progress in DNA base excision repair. Antioxid Redox Signal. 2014;20(4):708-26.

40. Kang L, Zhao W, Zhang G, Wu J, Guan H. Acetylated 8-oxoguanine DNA glycosylase 1 and its relationship with p300 and SIRT1 in lens epithelium cells from age-related cataract. Exp Eye Res. 2015;135:102-8. 
41. Xu B, Kang L, Zhang G, Wu J, Zhu R, Yang M, Guan $H$. The changes of 8OHdG, hOGG1, APE1 and Pol $\beta$ in lenses of patients with age-related cataract. Curr Eye Res. 2014;40(4):378-85.

42. Wang Y, Li F, Zhang G, Kang L, Qin B, Guan H. Altered DNA methylation and expression profiles of 8-oxoguanine DNA glycosylase 1 in lens tissue from age-related cataract patients. Curr Eye Res. 2014(0):1-7

43. Kershaw RM, Hodges NJ. Repair of oxidative DNA damage is delayed in the Ser326Cys polymorphic variant of the base excision repair protein OGG1. Mutagenesis. 2012:ges012

44. Ali K, Mahjabeen I, Sabir M, Mehmood H, Kayani MA. OGG1 mutations and risk of female breast cancer: meta-analysis and experimental data. Dis Markers. 2015;2015.

45. Su S, Yao Y, Zhu R, Liang C, Jiang S, Hu N, Zhou J, Yang M, Xing Q, Guan H. The associations between single nucleotide polymorphisms of DNA repair genes, DNA damage, and age-related cataract: Jiangsu Eye Study. Invest Ophthalmol Vis Sci. 2013;54(2):1201-7.

46. Mori T, Wanaka A, Taguchi A, Matsumoto K, Tohyama M. Differential expressions of the eph family of receptor tyrosine kinase genes (sek, elk, eck) in the developing nervous system of the mouse. Mol Brain Res. 1995; 29(2):325-35.

47. Petty A, Myshkin E, Qin H, Guo H, Miao H, Tochtrop GP, Hsieh J-T, Page P, Liu L, Lindner DJ. A small molecule agonist of EphA2 receptor tyrosine kinase inhibits tumor cell migration in vitro and prostate cancer metastasis in vivo. PLoS One. 2012;7(8):e42120.

48. Kinch MS, Zantek ND, Hein PW. EPHA2 as a therapeutic target for cancer. In: Google Patents; 2013

49. Xiao Z, Jackson D, Tice DA. EphA2 Immunoconjugate. In: Antibody-Drug Conjugates and Immunotoxins. Springer; 2013. p 241-253

50. Dunne PD, McArt DG, Blayney JK, Dasgupta S, Salto-Tellez M, Johnston PG, Van Schaeybroeck S. EpHA2 is an essential driver of invasion and a novel target in KRAS mutant colorectal cancer. Cancer Res. 2014;74(19 Supplement):2079.

51. Kato K, Sakamoto A, Kojima T, Hasegawa T, Ikeda S. An agonistic antibody to EphA2 exhibits anti-tumor effect to human melanoma. Cancer Res. 2015; 75(15 Supplement):1676.

52. Yang J, Li D, Fan Q, Cai L, Qiu X, Zhou P, Lu Y. The polymorphisms with cataract susceptibility impair the EPHA2 receptor stability and its cytoprotective function. J Ophthalmol. 2015;2015.

53. Bassnett S, Wilmarth PA, David LL. The membrane proteome of the mouse lens fiber cell. Mol Vis. 2009;15:2448.

54. Zhang T, Hua R, Xiao W, Burdon KP, Bhattacharya SS, Craig JE, Shang D, Zhao X, Mackey DA, Moore AT. Mutations of the EPHA2 receptor tyrosine kinase gene cause autosomal dominant congenital cataract. Hum Mutat. 2009:30(5):E603-11.

55. Kaul H, Riazuddin SA, Shahid M, Kousar S, Butt NH, Zafar AU, Khan SN, Husnain T, Akram J, Hejtmancik JF. Autosomal recessive congenital cataract linked to EPHA2 in a consanguineous Pakistani family. Mol Vis. 2010;16:511.

56. Dave A, Laurie K, Staffieri SE, Taranath D, Mackey DA, Mitchell P, Wang JJ, Craig JE, Burdon KP, Sharma S. Mutations in the EPHA2 gene are a major contributor to inherited cataracts in South-Eastern Australia. PLoS One. 2013;8(8):e72518.

\section{Submit your next manuscript to BioMed Central and we will help you at every step:}

- We accept pre-submission inquiries

- Our selector tool helps you to find the most relevant journal

- We provide round the clock customer support

- Convenient online submission

- Thorough peer review

- Inclusion in PubMed and all major indexing services

- Maximum visibility for your research

Submit your manuscript at www.biomedcentral.com/submit

) Biomed Central 